\title{
PENGEMBANGAN MEDIA LEMBAR KERJA SISWA (LKS) BERBASIS WEB PADA MATA PELAJARAN JARINGAN DASAR
}

\author{
Juaeni Abadi ${ }^{1}$, Baiq Desi Dwi Arianti ${ }^{2}$, Rasyid Hardi Wirasasmita ${ }^{3}$ \\ ${ }^{1,2,3}$ Program Studi Pendidikan Informatika, \\ Fakultas Keguruan dan Ilmu Pendidikan, Universitas Hamzanwadi \\ Email : juaeni.abadi89@gmail.com ${ }^{1}$, baiqdesidwiarianti@gmail.com ${ }^{2}$ \\ rasyidhw.p.informatika@gmail.com ${ }^{3}$
}

\begin{abstract}
Abstrak
Tujuan penelitian ini adalah untuk mengembangkan bahan ajar yang berupa Lembar Kerja Siswa Berbasis Web pada mata pelajaran Jaringan dasar di SMK Negeri 1 Sikur melalui proses pengembangan web design serta pengujian unjuk kerja dan kelayakan sistem. Model pengembangan yang digunakan pada penelitian ini adalah System Development Life Cycle (SDLC) Model dengan metode Waterfall yang terdiri dari 4 tahap utama pengembangan. Tahap pertama adalahan analisis kebutuhan ,yang dibagi menjadi 2 yaitu analisis fungsional dan analisis pengembangan. Tahap kedua adalah Desain, terdiri dari desain system menggunakan UML, desain interface serta desain database. Tahap ketiga adalah implementasi dan tahap keempat adalah pengujian. Berdasarkan hasil pengujian perangkat lunak yang telah dikembangkan menunjukkan hasil seperti berikut: 1) pembuatan bahan ajar berupa Lembar Kerja Siswa Berbasis Web telah melalui proses pengembangan web dari analisis hingga pengujian yang sesuai dengan web check list dan fungsi sistem; 2) unjuk kerja dari bahan ajar yang berupa Lembar Kerja Siswa Berbasis Web secara keseluruhan masuk dalam kategori "Layak" dengan tingkat persentase 78,94\%.
\end{abstract}

Kata Kunci : Bahan Ajar, Lembar Kerja Siswa Berbasis Web, Waterfall Method

\begin{abstract}
The aims of this study is to develop teaching materials in the form of Web-Based Student Worksheet on the subjects of Basic Network at SMK Negeri 1 Sikur through web design development process and performance testing and system feasibility. The development model used in this research is the System Development Life Cycle (SDLC) Model with Waterfall method consisting of 4 main stages of development. The first stage is the analysis requirement that is divided into 2 namely the functional analysis and development analysis. The second stage is Design, consisting of system design using UML, interface design as well as database design. The third stage is the implementation and the fourth stage is testing, Based on the results of software testing that has been developed shows the results as follows: (1) manufacture of teaching materials in the form of Web-Based Student Worksheet has been through the process of web development from analysis to testing in accordance with web check list and system functions, (2) the performance of teaching materials in the form of Web-Based Student Worksheet as a whole fall into the category of "Eligible" with a percentage rate of $78.94 \%$.
\end{abstract}

Keywords : Teaching Materials, Web Based Students Worksheet, Waterfall Method

\section{PENDAHULUAN}

Perkembangan teknologi informasi yang semakin berkembang pesat memungkinkan seseorang untuk melakukan eksplorasi data dan informasi secara lebih efektif dan praktis. Perkembangan ilmu pengetahuan dan teknologi juga telah membawa perubahan pesat dalam aspek kehidupan manusia untuk mencari dan mendapatkan informasi dengan mudah serta 
tidak terkendala oleh ruang dan waktu. Perkembangan tersebut telah dimanfaatkan di berbagai negara, institusi, dan ahli untuk berbagai kepentingan termasuk untuk pendidikan atau pembelajaran. Berbagai percobaan untuk mengembangkan perangkat pendidikan atau pembelajaran terus dilakukan (Rusman, 2012:342).

Media pembelajaran sendiri adalah setiap orang, bahan, alat, atau peristiwa yang dapat menciptakan kondisi yang memungkinkan siswa menerima pengetahuan, keterampilan, dan sikap. Dengan demikian, guru, buku ajar, dan lingkungan merupakan media pembelajaran (Anitah, 2010:2). Disamping itu, Perubahan paradigma belajar telah merubah pemahaman tentang pembelajaran, yaitu dari pengajaran (teaching) yang berpusat pada guru (teacher-centered learning) ke pembelajaran (learning) berpusat pada siswa (studentcentered learning) (Asyhar, 2011: 15).

Penggunaan TIK dalam pembelajaran sesuai dengan tuntutan kurikulum 2013. TIK mempunyai fungsi sebagai gudang ilmu pengetahuan. TIK juga berfungsi sebagai alat bantu pembelajaran bagi guru, siswa, serta alat bantu interaksi antara guru dengan siswa. Dimana media pembelajaran sendiri adalah setiap orang, bahan, alat, atau peristiwa yang dapat menciptakan kondisi yang memungkinkan siswa menerima pengetahuan, keterampilan, dan sikap. Dengan demikian, guru, buku ajar, dan lingkungan merupakan media pembelajaran (Anitah, 2010:2).

Berdasarkan hasil observasi di SMKN 1 Sikur bahwa kelengkapan sarana dan prasarana laboratorium komputer sesuai dengan standar minimal sarana dan prasarana, fasilitas internet sudah tersedia dan sesuai dengan standar minimal koneksi internet.Sedangkan berdasarkan hasil wawancara dengan siswa bahwa penggunaan media yang digunakan oleh guru lebih banyak menggunakan modul dan LKS cetak.

Penelitian dan pengembangan media pembelajaran dapat diterapkan diberbagai bidang serta banyak dilakukan seiiring dengan berkembangnya teknologi. Salah satu diantaranya adalah kajian yang dilakukan oleh Rahman (2016) mengatakan bahwa Media pembelajaran berbasis web (e-learning) umumnya telah banyak dimanfaatkan dalam proses pembelajaran seperti hypermedia, Moodle, dan Wewebsite (website). Satu diantaranya adalah media pembelajaran berbasis web yang banyak digunakan sebagai sumber pembelajaran dimana dari hasil penelitian tersebut ketercapaian hasil belajar dan terlaksanya aktivitas peserta didik dan pendidik sesuai indikator yang ditetapkan sehingga peserta didik dan pendidik pada saat proses pembelajaran berada pada kategori sangat baik.

Berdasarkan uraian diatas perlu dikembangkan inovasi baru di SMKN 1 sikur untuk memudahkan interaksi guru dan siswa dalam pembelajaran, sehingga peneliti tertarik untuk mengembangkan media berbasi web dengan judul "Pengembangan Lembar Kerja Siswa (LKS) Elektronik Berbasis Website Pada Mata Pelajaran Jaringan Dasar Kelas X-TKJ Di SMK Negeri 1 Sikur".

\section{METODE PENELITIAN}

Sesuai dengan permasalahan dan tujuan penelitian, maka penelitian ini menggunakan metode penelitian Research and Development (penemuan, pengembangan dan pengujian produk). Dalam bidang pendidikan, Borg and Gall yang dikutip oleh Sugiyono (2011) menyatakan bahwa, penelitian dan pengembangan (research and development/R\&D), merupakan metode penelitian yang digunakan untuk mengembangkan atau memvalidasi produk-produk yang digunakan dalam pendidikan dan pembelajaran.

Peneliti membangun perangkat lunak ini menggunakan model pengembangan perangkat lunak System Development Life Cycle (SDLC) model proses waterfall. Model proses 
waterfall adalah Metode air terjun atau yang sering disebut metode waterfall. Metode waterfall ini pernah juga digunakan dalam kajian yang berjudul Perancangan Web Based Learning Sebagai Media Pembelajaranberbasis Ict (Firmansyah, dkk. 2016), dimana proses pengembangan spesifikasi sistem baru berdasarkan hasil rekomendasi analisis sistem. Dalam tahap perancangan, tim kerja desain harus merancang spesifikasi yang dibutuhkan dalam berbagai kertas kerja. Kertas kerja itu harus memuat berbagai uraian mengenai input, proses, dan output dari sistem yang diusulkan. Sedangkan menurut (Pressman,2012) Metode waterfall sering dinamakan siklus hidup klasik (classic life cycle), dimana hal ini menggambarkan pendekatan yang sistematis dan juga berurutan pada pengembangan perangkat lunak, dimulai dengan spesifikasi kebutuhan pengguna lalu berlanjut melalui tahapan-tahapan perencanaan (planning), permodelan (modeling), konstruksi (construction), serta penyerahan sistem ke para pelanggan/pengguna (deployment), yang diakhiri dengan dukungan pada perangkat lunak lengkap yang dihasilkan. Beberapa penelitian yang telah mengembangkan pembelajaran berbasis web dengan menggunakan metode watarfall (Pascapraharastyan, dkk. 2014; Firmansyah, dkk. 2018; Hermawan, dkk. 2015; Rohayati. 2014). Berikut adalah tahapan-tahapan dalam model waterfall.

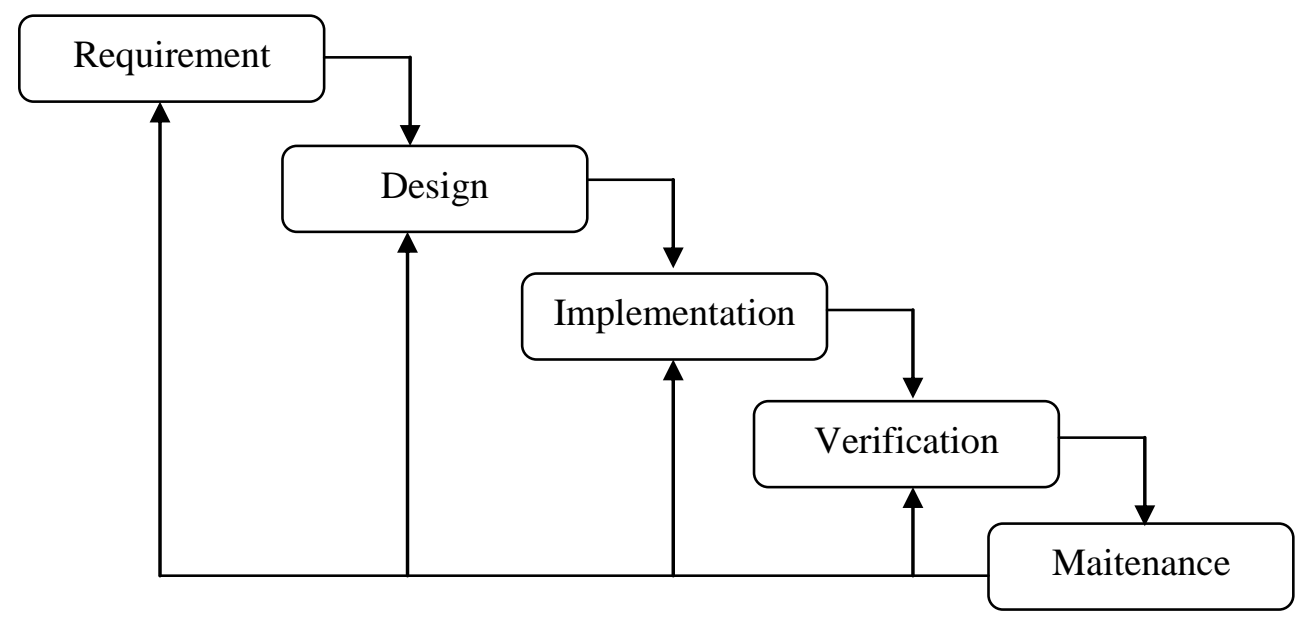

Gambar 1 : Diagram Model Waterfall

Analisis kebutuhan antara lain menentukan software yang akan digunakan dalam pembuatan bahan ajar berbasis web, serta fungsi-fungsi yang akan ada dalam di dalamnya. Analisis kebutuhan dilakukan identifikasi kebutuhan apa saja yang diperlukan dalam perancangan lembar kerja siswa berbasis web ini dibagi menjadi 2 jenis kebutuhan, yaitu kebutuhan fungsional adalah kebutuhan yang dibutuhkan untuk mendefinisikan fungsi yang akan ada di dalam LKS berbasis web sedangkan kebutuhan sistem adalah Tools yang akan digunakan untuk pengembangan lembar kerja siswa elektronik berbasis web.

Pengujian merupakan proses menemukan kesalahan yang mungkin terjadi setelah perangkat lunak selesai dibuat. Pengujian dilakukan dengan cara memberikan penilaian pada lembar kerja siswa elektronik berbasis web untuk menentukan kelayakan dari perangkat lunak tersebut.

Pengujian lembar kerja siswa berbasis web ini dilakukan dalam dua tahapan, yaitu Alfa testing dan beta testing. Dikutip dari jurnal Meisadri, dkk (2013) mengatakan alfa testing adalah Pengujian yang dilakukan terhadap aplikasi untuk memastikan bahwa aplikasi dapat berjalan dengan benar sesuai dengan kebutuhan dan tujuan yang diharapkan.. Pengujian yang digunakan pada game ini ada 2 (dua), yaitu teknik pengujian white box testing dan black box 
testing, sedangkan pengujian beta testing dilakukan secara langsung terhadap pengguna dengan menggunakan kuesioner mengenai kepuasan pengguna atas game yang telah dibangun. Adapun metode penilaian pengujian yang digunakan adalah metode kuantitatif berdasarkan data dari pengguna.

dalam hal ini adalah siswa kelas X- TKJ. Pengujian beta dilakukan untuk mendapatkan usulan dari pengguna akhir sebelum persiapan rilis produk akhir.

Tempat penelitian dilakukan di SMK Negeri 1 Sikur Lombok Timur. Penelitian ini dilakukan pada bulan Desember 2017 sampai bulan April 2018.

Teknik Pengumpulan Data yang digunakan dalam penelitian ini adalah :

1. Teknik observasi dilakukan untuk mengumpulkan data dalam penelitian ini terkait dengan aspek functionality, reliability, dan compatibility pada proses pengujian perangkat lunak.

2. Kuesioner dalam penelitian ini diberikan pada ahli materi, ahli media dan siswa. Kuesioner digunakan untuk mengetahui kualitas dan kelayakan media pembelajaran

Teknik analisis data dilakukan pada pengambilan data menggunakan kuesioner pada pengujian alpha dan beta. Pengambilan sampel dilakukan dengan menggunakan teknik purposive sampling. Sampling Purposive adalah teknik penentuan sampel dengan pertimbangan tertentu (Sugiyono, 2010:124).

Data yang dihasilkan dari kuesioner tersebut merupakan gambaran pendapat atau persepsi pengguna media pembelajaran. Data yang dihasilkan dari kuesioner tersebut merupakan data kuantitatif. Data tersebut dapat dikonversi ke dalam data kualitatif dalam bentuk interval menggunakan Skala Likert. Skala Likert merupakan metode pengukuran yang digunakan untuk mengukur sikap, pendapat dan persepsi seseorang atau kelompok orang tentang fenomena sosial (Sugiono, 2012).

Penelitian ini menggunakan kuesioner yang terdapat lima macam jawaban dalam setiap item pertanyaan. Data tersebut diberi skor sebagai berikut:

Tabel 1. Data Skor Jawaban

\begin{tabular}{cc}
\hline Jawaban & Skor \\
\hline Sangat Setuju & 5 \\
Setuju & 4 \\
Ragu-ragu & 3 \\
Tidak Setuju & 2 \\
Sangat Tidak Setuju & 1 \\
\hline
\end{tabular}

Analisi deskriptif dilakukan dengan perhitungan sebagai berikut:

Prsentase kelayakan $(100 \%)=\frac{\text { Skor Yang Diobservasi }}{\text { Skor Yang Diharapkan }} \times 100 \%$

Hasil perhitungan di atas кemudian algunakan untuk menentukan kelayakan media. Klasifikasi di bagi menjadi lima kategori pada skala likert. Berikut merupakan pembagian rentang kategori kelayakan media. 
Tabel 2. Kategori Kelayakan

\begin{tabular}{cc}
\hline Kategori & Presentase \\
\hline Sangat Layak & $81 \%-100 \%$ \\
Layak & $61 \%-80 \%$ \\
Cukup Layak & $41 \%-60 \%$ \\
Tidak Layak & $21 \%-40 \%$ \\
Sangat Tidak Layak & $0 \%-20 \%$ \\
\hline
\end{tabular}

\section{HASIL DAN PEMBAHASAN}

\section{A. Hasil Pengembangan}

Pengembangan produk Media Lembar Kerja Siswa (LKS) berbasis Web pada mata pelajaran Jaringan Dasar kelas X-TKJ di SMK Negeri 1 Sikur telah menyelesaikan serangkaian tahapan yang disesuaikan dari model pengembangan Borg \& Gall yang dikutip oleh Sugiyono (2011).

Dalam hasil penelitian ini akan diuraikan tentang hasil pengembangan mulai dari penelitian dan pengumpulan data awal sampai dengan revisi produk akhir. Pengembangan Media Lembar Kerja Siswa berbasis Web pada mata pelajaran Jaringan Dasar kelas XTKJ di SMK Negeri 1 Sikur dikembangkan berdasarkan data yang diperoleh melalui obeservasi pengamatan ke lapangan.

Hasil pengembangan media lembar kerja siswa berbasis web ini dapat dilihat pada gambar berikut ini.

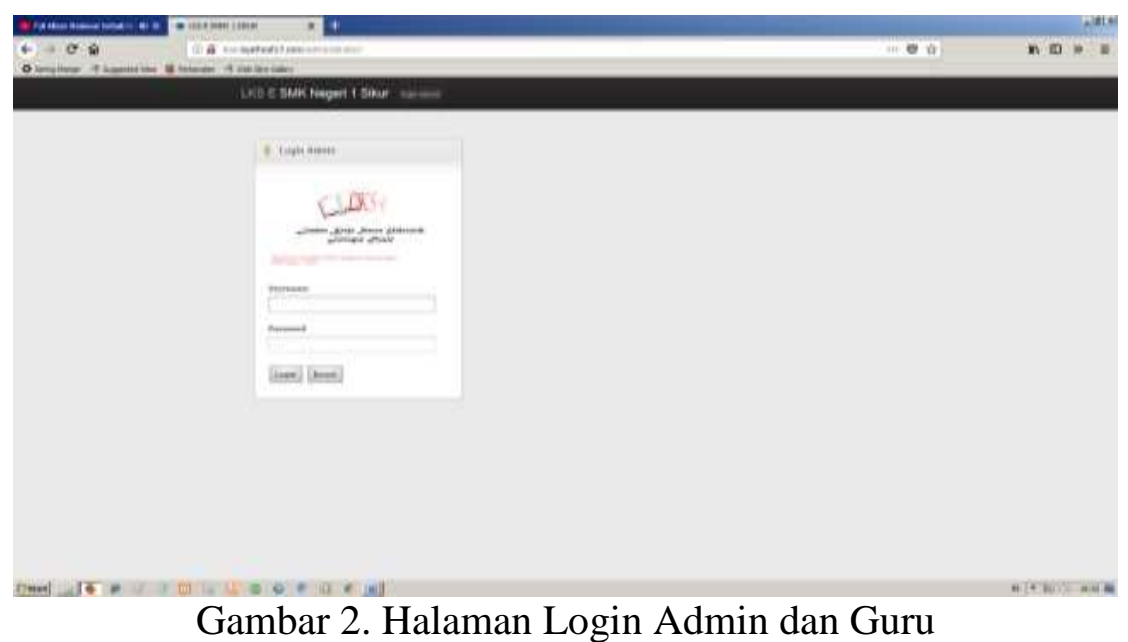

Pada interface login administrator dan guru terdapat form username, pasword, button login, riset password serta button menu login siswa 
Volume 2, Nomor 1, Juni 2018

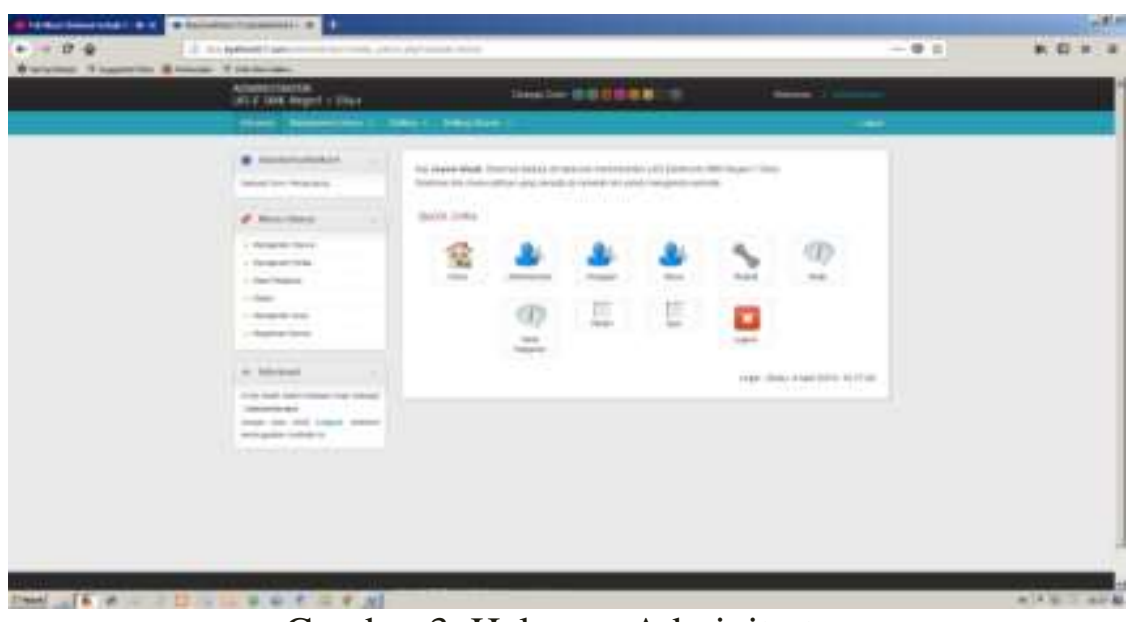

Gambar 3. Halaman Adminitrator

Pada akun administrator terdapat menu untuk pengolahan admin, pengolahan pengajar, pengolahan kelas, pengolahan siswa, modul, mata pelajaran, materi pembelajaran, quiz dan logout.

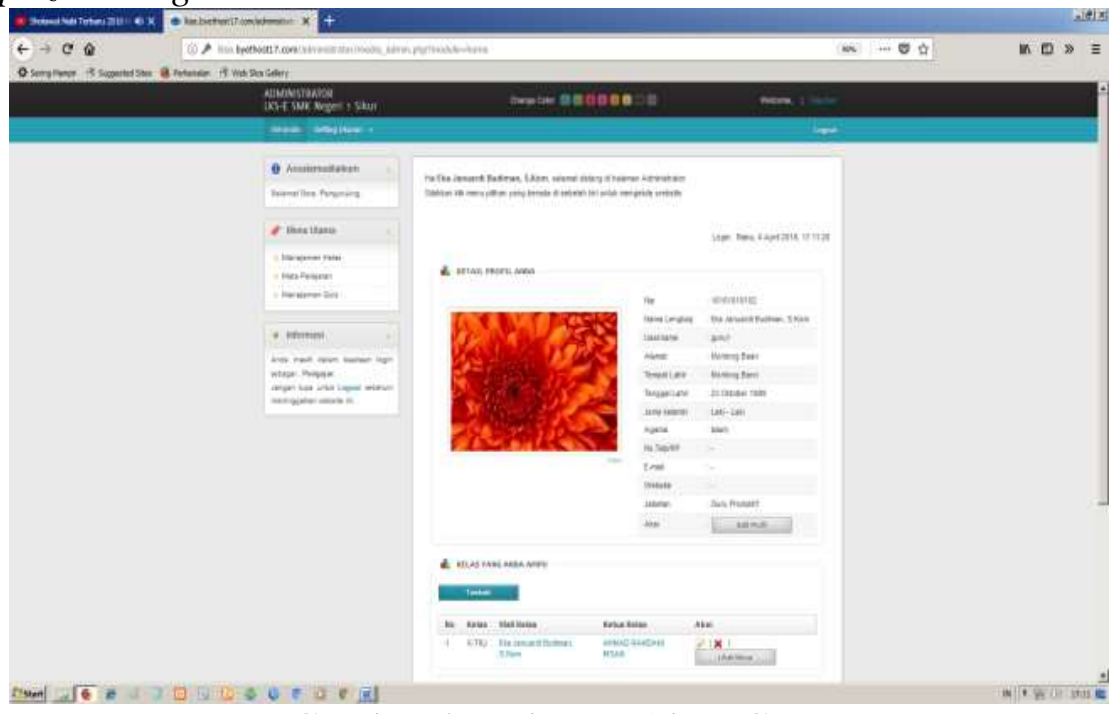

Gambar 4. Halaman Akun Guru

Pada akun guru terdapat menu untuk mengatur manajemen kelas, mata pelajaran dan quiz. Guru juga dapat melakukan edit profil mulai dari NIP sampai dengan mengganti foto profil. 


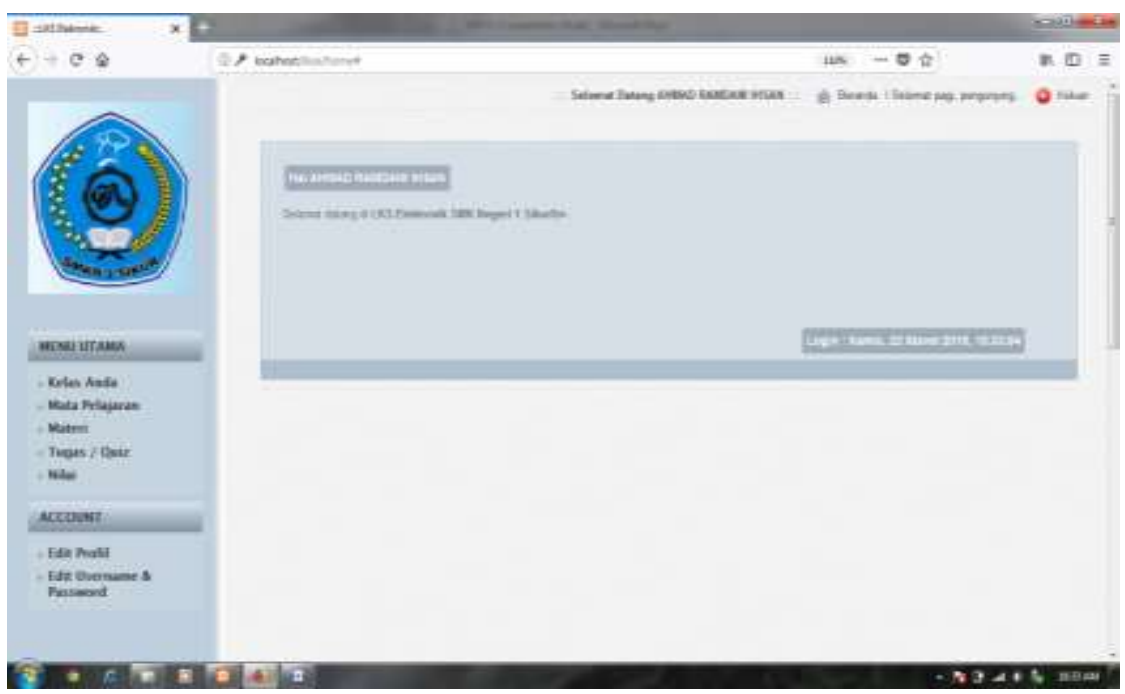

Gambar 5. Halaman Akun Siswa

Halaman ini akun siswa berisi Kelas siswa, mata pelajaran, materi, tugas/quiz dan nilai tugas siswa

\section{B. Pembahasan}

Pada tahap pengujian data uji coba media pembelajaran ini diperoleh dari validasi ahli media, validasi ahli materi dan uji coba pada siswa dengan mengisi instrument berupa kuesinoner pengujian kelayakan media pembelajaran. Instrumen penilaian yang akan digunakan diadaptasi dari daftar analisis kebutuhan.

\section{Pengujian Alfa Testing}

Tahap pengujian alfa testing dilakukan validasi oleh ahli media dan ahli materi dilakukan untuk menguji aspek usability, functionality. Pada tahap ini validasi pengujian media pembelajaran.

a) Pada alfa testing dilakukan pengujian oleh ahli media, dapat ditunjukkan oleh tabel berikut:

Tabel 3. Analisis Hasil Pengujian Ahli Media

\begin{tabular}{clcccc}
\hline No & Aspek Penilaian & $\begin{array}{c}\text { Jml } \\
\text { Butir }\end{array}$ & $\begin{array}{c}\text { Skor } \\
\text { Ahli } \\
\text { Media }\end{array}$ & $\begin{array}{c}\text { Skor Yang } \\
\text { Diharapkan }\end{array}$ & $\begin{array}{c}\text { Presentase } \\
\text { Kelayakan }\end{array}$ \\
\hline 1 & Usability & 8 & 34 & 40 & $85,00 \%$ \\
2 & Functionality & 13 & 60 & 65 & $92,31 \%$ \\
3 & Komunikasi Visual & 6 & 24 & 30 & $80,00 \%$ \\
\hline$\quad$ Jumlah & 27 & 118 & 135 & \\
\hline & Skor Reta-rata & & & & $85,77 \%$ \\
\hline
\end{tabular}

Berdasarkan tabel hasil penilaian media pembelajaran oleh ahli media didapat skor persentase kelayakan dari aspek usability 85,00\%, aspek functionality $92,31 \%$ sedangkan dari aspek komunikasi visual sebesar $80 \%$, sehingga didapat rerata persentase kelayakan yaitu $\mathbf{8 5 , 7 7 \%}$ Berdasarkan kategori kelayakan pada Tabel 4, maka media pembelajaran berbasis web dalam kriteria kelayakan "Sangat Layak". 
b) Pada alfa testing dilakukan pengujian oleh ahli materi secara garis besar dapat ditunjukkan oleh tabel berikut:

Tabel 4. Analisis Hasil Pengujian Ahli Media

\begin{tabular}{llcccr} 
No & Aspek Penilaian & $\begin{array}{c}\text { Jml } \\
\text { Butir }\end{array}$ & $\begin{array}{c}\text { Skor } \\
\text { Ahli } \\
\text { Media }\end{array}$ & $\begin{array}{c}\text { Skor Yang } \\
\text { Diharapkan }\end{array}$ & $\begin{array}{r}\text { Presentase } \\
\text { Kelayakan }\end{array}$ \\
\hline 1 & Usability & 6 & 23 & 30 & $76,67 \%$ \\
2 & Functionality & 8 & 30 & 40 & $75,00 \%$ \\
3 & Komunikasi Visual & 6 & 24 & 30 & $80,00 \%$ \\
\hline \multicolumn{2}{r}{ Jumlah } & 20 & 77 & 100 & \\
\hline & Skor Reta-rata & & & $77,22 \%$ \\
\hline
\end{tabular}

Berdasarkan tabel kategori kelayakan tabel hasil penilaian ahli materi menunjukan bahwa aspek desain pembelajaran mendapat presentase kelayakan sebesar 76,67\%, aspek isi materi mendapat 75,00\%, sedangkan aspek bahasa dan komunikasi $80 \%$. Hasil rerata dari ketiga aspek tersebut sebesar $\mathbf{7 7 , 2 2 \%}$. Berdasarkan kategori kelayakan pada Tabel 4, maka media pembelajaran dalam kriteria kelayakan "Layak".

2. Beta testing

Beta Testing dilakukan untuk menguji kualitas media dari aspek usability. Siswa membuka dan menggunakan media pembelajaran kemudian memberikan penilaian dengan mengisi kuesioner. Kuesioner yang digunakan adalah kuesioner Computer Usability atisfaction Questionnairres dengan beberapa perubahan agar sesuai dengan media yang diujikan. Dari hasil responden pada siswa sebanyak 32 siswa maka hasil tabulasi dapat ditunjukan oleh tabel berikut :

Tabel 5. Hasil Beta Testing

\begin{tabular}{cccc}
\hline $\begin{array}{c}\text { No } \\
\text { Soal }\end{array}$ & $\begin{array}{c}\text { Skor } \\
\text { Responden } \\
\text { 32 Siswa }\end{array}$ & $\begin{array}{c}\text { No } \\
\text { Soal }\end{array}$ & $\begin{array}{c}\text { Skor } \\
\text { Responden } \\
\text { 32 Siswa }\end{array}$ \\
\hline 1 & 132 & 11 & 131 \\
2 & 133 & 12 & 131 \\
3 & 121 & 13 & 125 \\
4 & 117 & 14 & 125 \\
5 & 120 & 15 & 134 \\
6 & 133 & 16 & 136 \\
7 & 134 & 17 & 132 \\
8 & 119 & 18 & 118 \\
9 & 121 & 19 & 126 \\
10 & 112 & & \\
\hline \multicolumn{5}{c}{} \\
\hline
\end{tabular}

Hasil penilaian dari siswa terhadap media pembelajaran berbasis web dengan aspek 
usability dengan 19 butir pertanyaan diperoleh skor sebagai berikut.

$$
\begin{aligned}
& \text { Prsentase kelayakan }(100 \%)=\frac{2.400}{3.040} \times 100 \% \\
& \text { Prsentase kelayakan }(100 \%)=78,91 \%
\end{aligned}
$$

berdasarkan hasil pengolahan data yang dilakukan pengguna maka di dapatkan hasil perhitungan secara keseluruhan yaitu 78,91\%. Sehingga dapat disimpulkan kualitas sistem masuk dalam kategori "Layak".

\section{SIMPULAN}

Berdasarkan penelitian yang dilakukan peneliti dalam Pengembangan Lembar Kerja Siswa berbasis web ini maka peneliti mengambil kesimpulan :

1. Hasil dari unjuk kerja bahan ajar berbasis website yang berupa media Lembar Kerja Siswa berbasis website pada mata pelajaran jaringan dasar di SMKN 1 Sikur adalah sistem telah memenuhi aspek - aspek kualitas web design yang baik. Hasil ini di dukung berdasarkan pengujian alpha testing oleh ahli media dengan katagori "Sangat Layak" berdasarkan hasil pengujian dari aspek usability sebesar $85,00 \%$, functionality presentase kelayakan sebesar $92,31 \%$, Komunikasi Visual presentase kelayakan sebesar $80,00 \%$, sehingga dengan demikian rata - rata presentase kelayakan ahli media sebesar $85,77 \%$ sedangakan dari ahli materi apla testing dengan katagori "Layak" berdasarkan hasil pengujian dari aspek usability sebesar 76,67\%, functionality presentase kelayakan sebesar 75,00\%, Komunikasi Visual presentase kelayakan sebesar $80,00 \%$, sehingga dengan demikian rata - rata presentase kelayakan ahli media sebesar $77,22 \%$

2. Hasil dari kelayakan media LKS berbasis website pada mata pelajaran jaringan dasar di SMKN 1 Sikur adalah dalam kategori "Layak". Hasil pengujian kelayakan ini didukung berdasarkan hasil pengujian beta yang dilakukan oleh pengguna dengan jumlah persentase angket pengujian dengan teknik purposive sampling yang dihasilkan adalah 78,94\%. Deskripsi persentase dari kualitas sistem tersebut masuk dalam kategori "Layak".

\section{REFERENSI}

Arsyad, Azhar. (2014). Media Pembelajaran. Jakarta: PT Rajagrafindo Persada.

Anitah, S. (2010). Media Pembelajaran. Surakarta: Yuma Pustaka.

Firmansyah R, Saidah I. (2016). Perancangan Web Based Learning Sebagai Media Pembelajaran Berbasis ICT. Informatika. 3(2): 176-182.

Firmansyah Y, Udi. (2018). Penerapan Metode SDLC Waterfall Dalam Pembuatan Sistem Informasi Akademik Berbasis Web Studi Kasus Pondok Pesantren Al-Habi Sholeh Kabupaten Kubu Raya, Kalimantan Barat. Jurnal Teknologi dan Manajemen Informasi. 4 (1): 184-191

Hermawan R, Hidayat h, Utomo G.F. (2015). Sistem Informasi Penjadwalan Kegiatan Belajar Mengajar Berbasis Web. Jurnal Evolusi. 2015. 3(2). 
Volume 2, Nomor 1, Juni 2018

Meisadri R, Indriani N. (2013). Pembangunan Game First Person Shooter 3d Alien Hunter. Jurnal Ilmiah Komputer dan Informatika (KOMPUTA). 2(1).

Pascapraharastyan A, Supriyanto A, Sudarmaningtyas, P. 2014. Rancang Bangun Sistem Informasi Manajemen Arsip Rumah Sakit Bedah Surabaya Berbasis Web. Jurnal Sistem Informasi. 3(1): 139-143.

Pressman, Roger S. (2002). Rekayasa Perangkat Lunak, Buku satu Pendekatan Praktisi (Edisi 7). Yogyakarta.

Rahman, Khaidir. (2016). Pengembangan Media Pembelajaran Berbasis Website Untuk Mata Pelajaran Programmable Logic Controller (PLC) Pada SMK Darussalam Makassar. Jurnal Inspiraton. 6 (2): 105-117.

Rohayati, M. (2014). Membangun Sistem Informasi Monitoring Data Inventory Di Vio Hotel Indonesia. Jurnal Ilmiah Komputer dan Informatika (KOMPUTA). 1(1): 1-8.

Rusman. (2012). Model-Model Pembelajaran: Mengembangkan Profesionalisme Guru. Jakarta: Rajawali Pers

Sugiyono. (2010). Metode Penelitian Kuantitatif, Kualitatif dan R\&D. Bandung: Afabeta

Sugiyono. (2011). Metode Penelitian Kuantitatif, Kualitatif dan R\&D. Bandung: Afabeta

Sugiyono. (2012). Metode Penelitian Kuantitatif Kualitatif dan R\&D. Bandung: Alfabeta. 